\title{
Xanthomonas Leaf Spot of Catnip: A New Disease Caused by a Pathovar of Xanthomonas campestris
}

\author{
Steven T. Koike, University of California Cooperative Extension, Salinas 93901; and Hamid R. Azad and Donald \\ A. Cooksey, Department of Plant Pathology, University of California, Riverside 92521
}

\begin{abstract}
Koike, S. T., Azad, H. R., and Cooksey, D. A. 2001. Xanthomonas leaf spot of catnip: A new disease caused by a pathovar of Xanthomonas campestris. Plant Dis. 85:1157-1159.

Xanthomonas leaf spot is a new disease that has occurred on catnip (Nepeta cataria). Catnip is grown commercially in California for use as herbs, seasonings, and tea. This disease has developed recently on catnip transplants that are produced in enclosed greenhouses. Symptoms consist of small brown flecks that are visible from both sides of a leaf. The flecks later develop into larger, dark brown, angular leaf spots. Severe infection reduced the quality and marketability of the transplants. Xanthomonas campestris, as identified by biochemical, physiological, and molecular tests, was consistently isolated from symptomatic plants, and selected strains caused similar symptoms when inoculated onto catnip test plants. However, catnip strains failed to cause any symptoms when inoculated onto nine other plants in the Lamiaceae family and five other hosts of known $X$. campestris pathovars. Catnip plants showed no symptoms when inoculated with $X$. campestris pvs. campestris, carotae, and vesicatoria. Catnip also was not susceptible to the $X$. campestris pathogen isolated from lavender. This is the first report of a bacterial disease of catnip caused by a Xanthomonas pathogen, and the catnip strains may be a new and distinct pathovar of $X$. campestris.
\end{abstract}

Additional keywords: hrp primers

Catnip (Nepeta cataria) is a perennial shrub in the Lamiaceae family and is probably best known as a plant that is attractive to cats. In California, the plant is grown and used for herbs, seasonings, and tea. Beginning in 1998, catnip grown commercially as transplants in California greenhouses exhibited symptoms of a previously undescribed foliar disease. Initial symptoms consisted of small brown flecks (1 to $2 \mathrm{~mm}$ diameter) on foliage that were visible from both adaxial and abaxial sides of the leaves. These flecks expanded into larger leaf spots ( 2 to $8 \mathrm{~mm}$ diameter) that were dark brown to black and angular in shape. When sections of leaf lesions were cut, mounted in water, and examined with phase-contrast microscopy, bacterial streaming was observed consistently. When grown in greenhouse conditions that included overhead sprinkler irrigation, transplants developed extensive leaf infections and had reduced plant growth and reduced quality and marketability. The purpose of this study was to determine and characterize the causal agent of this disease.

Corresponding author: S. T. Koike
E-mail: stkoike@ucdavis.edu

Accepted for publication 29 July 2001.

Publication no. D-2001-0904-01R

(C) 2001 The American Phytopathological Society

\section{MATERIALS AND METHODS}

Isolation of the causal agent. Symptomatic leaves were surface-sterilized $(0.525 \%$ sodium hypochlorite; $1 \mathrm{~min}$ ), and small (3 $\times 3 \mathrm{~mm}$ ) sections of tissue were excised aseptically from leaf spot margins and macerated individually in $40 \mu \mathrm{l}$ of sterile distilled water. The resulting suspensions were streaked onto sucrose peptone agar (SPA) (3) plates and incubated at $24^{\circ} \mathrm{C}$. After 3 to 5 days, representative bacterial strains were purified by restreaking single colonies onto SPA, then kept in $40 \%$ glycerol at $-70^{\circ} \mathrm{C}$ for routine use or lyophilized for long-term storage. To test for possible fungal pathogens, small, surface-sterilized leaf sections were removed aseptically and placed onto acidified potato dextrose agar ( $2 \mathrm{ml}$ of lactic acid per liter). Plates were incubated under lights at $24^{\circ} \mathrm{C}$ and examined after 3 to 10 days for fungal growth.

Identification of the bacteria. Isolated strains of recovered bacteria were tested for morphological, biochemical, and physiological characteristics. Gram and flagellar stains were performed as described by Schaad et al. (9). Standard tests necessary for identification of xanthomonads (catalase and oxidase reactions, arginine dihydrolase, ability to induce pitting on polypectate gel, and hypersensitive reaction on tobacco [Nicotiana tabacum cv. Turk] leaves) were conducted on the strains (9).

Bacteria also were characterized by determining their carbon source utilization profiles on Biolog GN microplates
(Biolog, Inc., Hayward, CA) and by fatty acid analysis. Bacteria were cultured on trypticase soy broth agar at $28^{\circ} \mathrm{C}$ for $24 \mathrm{~h}$, then extracted for fatty acid methyl esters using a standard method (10). Fatty acids were analyzed with the Sherlock Microbial Identification System Version 2.11 (MIDI Inc., Newark, DE) that used an automated GC 6890 Hewlett-Packard gas chromatograph fitted with a $25 \times 0.2 \mathrm{~mm}$ phenyl methyl silicone-fused silica capillary column, an HP 7673 automatic sampler, and HP Chem Station Software (10). Xanthomonas campestris pv. campestris (strain 0186-1) from cauliflower (Brassica oleracea subsp. botrytis) and $X$. campestris pv. vesicatoria (strain 0788-2) from tomato (Lycopersicon esculentum) were used as controls. For this study, we chose to follow the more traditional classification of xanthomonads as restated in Schaad et al. (9) rather than following the revised classification scheme of Vauterin et al. (11).

DNA amplification with hrp-related primers. Total bacterial genomic DNA was isolated by the cetytrimethylammonium bromide (CTAB) purification method essentially as described by Ausubel et al. (1). The primers (RST21 [5'GCACGCTCCAGATCAGCATCGAG G3'] and RST22 [5'GGCATCTGCATG CGTGCTCTCCGA3']) were designed originally by Leite et al. (8) to delineate a 1,075-bp fragment of the hypersensitivity reaction and pathogenicity (hrp) gene region of $X$. campestris pv. vesicatoria. DNA was amplified in a total volume of $100 \mu \mathrm{l}$ of reaction mixture, which contained $10 \mu \mathrm{l}$ of Vent DNA polymerase 10x buffer (NE BioLabs, Inc., Beverly, MA), $200 \mu \mathrm{M}$ each deoxynucleoside triphosphate (NE BioLabs), $0.1 \mu \mathrm{g}$ of BSA, $1 \mathrm{mM} \mathrm{MgSO}{ }_{4}, 5 \%$ DMSO, $1 \mu \mathrm{M}$ of each primer, and $1 \mu \mathrm{l}$ of Vent polymerase (4). The amount of template DNA added was $25 \mathrm{ng}$ of total bacterial DNA. PCR amplification was performed in an automated thermocycler (EasyCycler TM Series, Ericomp, Inc., San Diego, CA) using the following cycles: an initial denaturation of DNA template at $95^{\circ} \mathrm{C}$ for $5 \mathrm{~min}$; 24 cycles of denaturation at $95^{\circ} \mathrm{C}$ for $1 \mathrm{~min}$ each; annealing at $57^{\circ} \mathrm{C}$ for $30 \mathrm{~s}$; extension at $72^{\circ} \mathrm{C}$ for $1 \mathrm{~min}$; and a final extension at $72^{\circ} \mathrm{C}$ for $5 \mathrm{~min}$. Detection of amplified DNA was performed according to previously described procedures $(1,8)$.

Pathogenicity to catnip. Pathogenicity to catnip was demonstrated by growing inocula of nine individual strains in nutri- 
ent broth (Difco Laboratories, Detroit, MI; $8 \mathrm{~g} / \mathrm{liter}$ ) shake cultures for $48 \mathrm{~h}$. The resulting bacterial suspensions $\left(10^{6} \mathrm{CFU} / \mathrm{ml}\right.$ as determined with dilution plating) received either Tween $20(0.05 \%)$ and were sprayed onto potted catnip plants using a hand-held mister, or Carborundum and were inoculated by rubbing onto catnip leaves. Control plants were sprayed or rubbed with sterile nutrient broth plus Tween 20 or Carborundum, respectively. Twelve plants, each 2 months old, were used for each inoculation. After inoculation, plants were incubated in a dew chamber maintained at $18^{\circ} \mathrm{C}$ for $48 \mathrm{~h}$, then kept in a greenhouse at 22 to $24^{\circ} \mathrm{C}$. Plants were examined daily for symptoms. The experiment was done twice.

Pathogenicity to other plants in Lamiaceae. To test the ability of the catnip strains to infect other plants in the Lamiaceae family, inocula of five strains were produced as described previously. Each broth culture was inoculated by spraying or rubbing onto separate sets of 12 plants of each of the following: carpet bugle (Ajuga reptans cv. Mahogany), basil (Ocimum basilicum), coleus (Coleus blumei cv. Rainbow Mixed), English lavender (Lavandula angustifolia), oregano (Origanum vulgare), rosemary (Rosmarinus officinalis), salvia (Salvia farinacea cv. Blue Bedder), thyme (Thymus vulgaris), and spearmint (Mentha spicata). Catnip plants also were inoculated with the strains, and control plants of all species were spray- or rub-inoculated with sterile nutrient broth. After inoculation, plants were incubated in a dew chamber maintained at $18^{\circ} \mathrm{C}$ for $48 \mathrm{~h}$, then kept in a greenhouse at 22 to $24^{\circ} \mathrm{C}$. Plants were examined daily for symptoms. The experiment was done twice.

Host range comparison of $X$. campestris strains from catnip and other $X$. campestris hosts. To compare host ranges of $X$. campestris pathogens from catnip and other plants, bacterial colonies of four catnip strains (O-1, O-12, R-1, R-12), one $X$. campestris pv. campestris strain (01861) from cauliflower, one $X$. campestris pv. carotae strain (1199-54) from carrot (Daucus carota subsp. sativus), and one $X$. campestris pv. vesicatoria strain (0788-2) from tomato were grown on YDC agar for
$48 \mathrm{~h}$ at $28^{\circ} \mathrm{C}$ and then suspended in sterile distilled water at a concentration of $10^{6}$ $\mathrm{CFU} / \mathrm{ml}$, based on optical density readings with a Klett-Summerson colorimeter. The bacterial suspensions either were infiltrated into leaves using syringes or sprayed onto plants until runoff with an aerosolpropelled spray unit. Three plants each of the following were inoculated by each method: catnip, cauliflower, pepper (Capsicum annuum), tomato, and stock (Matthiola incana). Because of its very small leaves, carrot was inoculated only by spraying. These plant species were chosen because catnip transplants were grown in greenhouses that also contained transplants of several of these species (cauliflower, pepper, tomato) or because these species also are hosts of an $X$. campestris pathovar.

In another experiment, inocula were prepared of three strains (0894-4, 1294-6, 1294-9) of an $X$. campestris that was shown previously to be pathogenic on lavender (6). Inocula were prepared as described previously and were infiltrated or sprayed onto different sets of catnip and lavender plants.

All inoculated plants were misted intermittently for $24 \mathrm{~h}$ with incubation temperatures at 23 to $26^{\circ} \mathrm{C}$. Plants later were transferred to a greenhouse having ambient temperature at 17 to $22^{\circ} \mathrm{C}$. The plant reactions to inoculations were recorded every day for 30 consecutive days. All of these host range comparison inoculations were done twice.

\section{RESULTS}

Isolation and identification of the causal agent. Fungi were not observed on nor recovered from the leaf sections placed onto acidified potato dextrose agar plates. However, yellow, mucoid bacterial colonies were obtained consistently from symptomatic catnip leaves plated onto SPA. No other bacteria were isolated. Tests indicated that the recovered bacteria were Gram negative, catalase positive, oxidase negative, with single polar flagella. Strains were obligately aerobic and urease, arginine dihydrolase, and nitrate negative. Strains hydrolyzed starch, liquefied gelatin, were unable to accumulate PHB granules, and did not grow on a defined minimal medium lacking growth factors.
Infiltration of tobacco leaves with cell suspensions of the catnip strains all resulted in typical hypersensitivity reactions within $24 \mathrm{~h}$. Based on these characteristics, the bacterium was identified as Xanthomonas campestris $(7,9)$.

Biolog was useful for rapid identification of this bacterium. The Biolog data base identified all isolated strains as $X$. campestris, with similarity readings ranging from 57 to $79 \%$. The closest similarity was with $X$. campestris cv. juglandis. In cellular fatty acid analyses, the catnip strains were closely related to $X$. campestris, with similarity percentages ranging from 59 to $69 \%$. The closest similarity again was to $X$. campestris $\mathrm{cv}$. juglandis.

DNA amplification with hrp-related primers. Using the oligonucleotide primers for the $X$. campestris pv. vesicatoria hrp gene cluster, fragments of identical sizes $(1 \mathrm{~kb})$ were amplified from all $X$. campestris strains isolated from catnip as well as from $X$. campestris pvs. campestris and vesicatoria control strains.

Pathogenicity to catnip. When representative catnip strains were inoculated by either method onto catnip, small brown flecks developed on leaves after 4 to 5 weeks. One to 2 weeks later, these flecks developed into larger angular, brown spots. Both symptoms were similar to those observed on diseased transplants in commercial greenhouses. Bacteria morphologically similar to the original strains were isolated consistently from test plants and after characterization were confirmed to be identical to the original strains. Catnip inoculated with sterile broth did not develop any symptoms. Results from the two experiments were the same.

Pathogenicity to other Lamiaceae plants. After 4 to 5 weeks, inoculated catnip developed leaf spot symptoms characteristic of the disease and $X$. campestris was reisolated from leaves. However, none of the other Lamiaceae plants developed any symptoms, regardless of the inoculation method. After 8 weeks, the experiment was terminated for lack of symptoms. Results from the two experiments were the same.

Host range comparison of $X$. campestris strains from catnip and other $X$. campestris hosts. When four $X$. campestris

Table 1. Reaction of various hosts of Xanthomonas campestris when inoculated with known X. campestris strains or those isolated from catnip ${ }^{\mathrm{z}}$

\begin{tabular}{|c|c|c|c|c|c|c|c|c|}
\hline \multirow[b]{2}{*}{ Plant } & \multicolumn{4}{|c|}{ Infiltrated strain } & \multicolumn{4}{|c|}{ Sprayed strain } \\
\hline & $\begin{array}{l}4 \text { from } \\
\text { catnip }^{y}\end{array}$ & $\begin{array}{c}\text { pv. } \\
\text { campestris }\end{array}$ & $\begin{array}{c}\text { pv. } \\
\text { carotae }\end{array}$ & $\begin{array}{c}\text { pv. } \\
\text { vesicatoria }\end{array}$ & $\begin{array}{l}4 \text { from } \\
\text { catnip }^{y}\end{array}$ & $\begin{array}{c}\text { pv. } \\
\text { campestris }\end{array}$ & $\begin{array}{c}\text { pv. } \\
\text { carotae }\end{array}$ & $\begin{array}{c}\text { pv. } \\
\text { vesicatoria }\end{array}$ \\
\hline Catnip & +++ & + & + & - & +++ & - & - & - \\
\hline Carrot & NT & NT & NT & NT & - & - & +++ & - \\
\hline Cauliflower & + & +++ & + & + & - & +++ & - & - \\
\hline Pepper & + & + & + & +++ & - & - & - & +++ \\
\hline Stock & + & + & + & + & - & - & - & - \\
\hline Tomato & + & + & + & +++ & - & - & - & +++ \\
\hline
\end{tabular}

${ }^{\mathrm{z}}$ Reactions were evaluated as follows: $-=$ no reaction; $+=$ limited water-soaking, necrosis; $++=$ water-soaking, necrosis, leaf spot development; +++ = extensive leaf spot and disease development; NT = not tested. Results from the two experiments were the same and are combined in this table.

y All four catnip strains responded similarly. 
strains from catnip were infiltrated into leaves of catnip, cauliflower, pepper, stock, and tomato, water-soaking occurred on all plants within $24 \mathrm{~h}$. Water-soaked areas on all plant species turned into brown-black necrotic lesions after $48 \mathrm{~h}$. However, only catnip leaf lesions expanded beyond the initial infiltrated area during the test period (Table 1). Because the other plants did not develop any disease symptoms beyond the inoculated area, isolations were not done. However, bacteria morphologically similar to the original strains were isolated consistently from the catnip leaf lesions that formed beyond inoculation areas, and after characterization were confirmed to be identical to the original strains.

Catnip leaves infiltrated with $X$. campestris pvs. campestris and carotae also developed water-soaked, brown-black necrotic lesions after $48 \mathrm{~h}$; these areas likewise did not expand beyond the initial infiltrated area. Catnip leaves infiltrated with $X$. campestris pv. vesicatoria did not develop water-soaking or necrosis. In contrast, cauliflower leaves infiltrated with $X$. campestris pv. campestris, and pepper and tomato leaves infiltrated with $X$. campestris pv. vesicatoria all developed watersoaked lesions that became brown and necrotic. These lesions later expanded and developed into typical black rot and bacterial spot symptoms, respectively (Table 1). Bacteria morphologically similar to the original cauliflower and tomato strains were isolated consistently from symptomatic cauliflower, pepper, and tomato leaves, and after characterization were confirmed to be identical to the original strains. Results from the two infiltration inoculation experiments were the same.

When plants were inoculated by spraying, the four $X$. campestris strains from catnip caused typical leaf spot symptoms on catnip plants but failed to cause any symptoms on the other plants (Table 1). Catnip plants did not show any symptoms when inoculated by spraying with the $X$. campestris pvs. campestris, carotae, and vesicatoria. Carrot, cauliflower, pepper, and tomato developed leaf spots only in response to their respective pathogens. As with the infiltration experiments, each Xanthomonas pathovar was reisolated only from symptomatic leaves of its respective host. Results from the two spray inoculation experiments were the same.

In the second experiment, the three $X$. campestris strains from lavender caused limited water-soaking when infiltrated into catnip leaves but no symptoms when inoculated by spraying. However, these strains caused brown lesions when infiltrated or sprayed onto lavender plants, and $X$. campestris was reisolated from these lesions. Results from the two infiltration and two spray inoculation experiments were the same.

\section{DISCUSSION}

This appears to be the first report of a foliar bacterial disease of catnip caused by $X$. campestris. Named here as Xanthomonas leaf spot of catnip, the disease resulted in extensive leaf spotting and loss of quality of catnip transplants. In previous reports, catnip has been reported to be a natural host of Pseudomonas syringae pv. tabaci (2) and several fungal pathogens, namely Ascochyta leonuri, Botrytis cinerea, Cercospora nepetae, Didymella catariae, Phoma exigua, and Septoria nepetae (5).

Our inoculation experiments demonstrated that the $X$. campestris strains from catnip did not infect several other Lamiaceae plants or five other hosts of $X$. campestris pathovars, and that catnip is not susceptible to three known $X$. campestris pathovars or to the $X$. campestris pathogen of lavender. These data suggest that the catnip pathogen might be host specific to this plant and hence constitute a new pathovar. Additional studies would be needed to confirm this. It was notable that under our experimental conditions the catnip test plants took an extended time, i.e., 4 to 5 weeks, before showing the onset of symptoms. This delay in symptom expression was consistent throughout our studies.

Commercially produced catnip transplants were grown in enclosed greenhouses that also contained transplants of cauliflower, pepper, and tomato. Based on our inoculation studies, it appears that $X$. campestris pathogens from these other crops are not the cause of the bacterial disease of catnip, and the catnip transplants are not an inoculum source for Xanthomo- nas diseases of cauliflower, pepper, or tomato. These findings have important epidemiological implications, as greenhouse transplant managers will not need to be concerned about disease spreading from catnip onto the sizable cauliflower, pepper, or tomato transplant crops. The occurrence of this disease on catnip seedlings grown in enclosed greenhouses suggests that initial inoculum could possibly be seedborne.

\section{ACKNOWLEDGMENTS}

We thank Mike Atkins, Bill Devor, Diana Henderson, and Hernan Parra for their assistance with this research.

\section{LITERATURE CITED}

1. Ausubel, F. M., Brent, R., Kingston, R. E., Moore, D. D., Seidman, J. G., Smith, J. A., and Struhl, K., eds. 1987. Current Protocols in Molecular Biology. John Wiley \& Sons, New York.

2. Bradbury, J. F. 1986. Guide to Plant Pathogenic Bacteria. CAB International Mycological Institute, Slough, England.

3. Canteros de Echenique, B. I., Zagory, D., and Stall, R. E. 1985. A medium for cultivation of the B-strain of Xanthomonas campestris pv. citri, cause of cancrosis B in Argentina and Uruguay. Plant Dis. 69:122-123.

4. Cease, K. B., Potcova, C. A., Lohff, C. J., and Zeigler, M. E. 1994. Optimized PCR using Vent polymerase. PCR Methods Applications 3:298-300.

5. Farr, D. F., Bills, G. F., Chamuris, G. P., and Rossman, A. Y. 1989. Fungi on Plants and Plant Products in the United States. American Phytopathological Society, St. Paul, MN.

6. Koike, S. T., Tjosvold, S. A., Cooksey, D. A., and Azad, H. R. 1995. A bacterial leaf disease of lavender caused by Xanthomonas campestris. Plant Dis. 79:859.

7. Krieg, N. R., and Holt, J. G., eds. 1984. Bergey's Manual of Systematic Bacteriology. Vol. 1. Williams and Wilkins, Baltimore, MD.

8. Leite, R. P., Jr., Minsavage, G. V., Bonas, U., and Stall, R. E. 1994. Detection and identification of phytopathogenic Xanthomonas strains by amplification of DNA sequences related to the hrp genes of Xanthomonas campestris pv. vesicatoria. Appl. Environ. Microbiol. 60:1068-1077.

9. Schaad, N. W., Jones, J. B., and Chun, W., eds. 2001. Laboratory Guide for Identification of Plant Pathogenic Bacteria. 3rd ed. American Phytopathological Society, St. Paul, MN.

10. Stead, D. E. 1988. Identification of bacteria by computer-assisted fatty acid profiling. Acta Hortic. 225:39-46.

11. Vauterin, L., Hoste, B., Kersters, K., and Swings, J. 1995. Reclassification of Xanthomonas. Int. J. Syst. Bacteriol. 45:472-489. 